\title{
A multicentre mortality study of workers exposed to ethylene oxide
}

\author{
N Kiesselbach, K Ulm, H-J Lange, U Korallus
}

\begin{abstract}
A multicentre cohort study was carried out to study the possible association between exposure to ethylene oxide and cancer mortality. The cohort consisted of 2658 men from eight chemical plants of six chemical companies in the Federal Republic of Germany who had been exposed to ethylene oxide for at least one year between 1928 and 1981. The number of subjects in the separate plants varied from 98 to 604. By the closing date of the study (31 December 1982) 268 had died, 68 from malignant neoplasms. For 63 employees who had left the plant $(2 \cdot 4 \%)$ the vital status remained unknown. The standardised mortality ratio for all causes of death was 0.87 and for all malignancies 0.97 compared with national rates. When local state rates were used the SMRs were slightly lower. Two deaths from leukaemia were observed compared with 2.35 expected (SMR $=0 \cdot 85$ ). SMRs for carcinoma of the oesophagus $(2 \cdot 0)$ and carcinoma of the stomach $(1 \cdot 38)$ were raised but not significantly. In one plant an internal "control group" was selected matched for age, sex, and date of entry into the factory and compared with the exposed group. In both groups a "healthy worker effect" was observed. The total mortality and mortality from malignant neoplasms was higher in the exposed than in the control group; the differences were not statistically significant. There were no deaths from leukaemia in the exposed group and one in the control group.
\end{abstract}

Ethylene oxide (EO) has toxic effects on different organ systems. ${ }^{1}$ In short term tests it is genotoxic, has teratogenic properties, and in animals it causes malignant neoplasms (local fibrosarcomas after subcutaneous injections and stomach and brain tumours

Ärztliche Abteilung, Bayer AG, D-5090 Leverkusen, FRG

N Kiesselbach, U Korallus

Institut für Medizinische Statistik und Epidemiologie der Technischen Universität München, D-8000 München 80, FRG

K Ulm, H-J Lange after oral administration). In $1984 \mathrm{EO}$ was classified into category III A 2 of the German MAK-list (proved animal carcinogen).

EO irritates the skin and mucous membranes. After inhalation central nervous symptoms such as headaches, nausea, dyspnoea, and disturbances of $i$ coordination are observed. In higher concentrations it causes periodic vomiting and may cause burns after $\stackrel{\infty}{N}$ skin contact. ${ }^{2}$ Chromosomal aberrations ${ }^{3}$ and sister 옹 chromatid exchanges ${ }^{4}$ have been described in man. The possibility of raised rates of miscarriages for women engaged in EO sterilisation in hospital has also been discussed. ${ }^{5}$

Two Swedish studies have reported a raised SMR for leukaemia ${ }^{67}$ In one of these studies an additional raised rate from stomach carcinoma was also mentioned. A further study reported one case each of myelogenous leukameia and lymphosarcoma. ${ }^{8}$

In a fourth study, however, no case of leukaemia was observed. ${ }^{9}$ The question of the carcinogenicity of EO for man therefore still remains open; this view is confirmed by more recent reviews. ${ }^{1011}$

These differing published observations induced the Verband der Chemischen Industrie (VCI) to start its own study of exposure to EO in its member companies. The aim was the investigation of a possible association between exposure to $\mathrm{EO}$ and mortality (total mortality and mortality due to leukaemia or other types of neoplasms). The investigation was carried out by means of historic cohort study with the calculation of SMRs.

\section{Methods and materials}

STUDY DESIGN

Since only relatively few employees exposed to EO could be included in an epidemiological study from each producer or processor of EO in the Federal Republic of Germany it was decided to conduct a $\mathrm{\omega}$ multicentre study in eight plants of the chemical $\%$ industry. ${ }^{\star}$ All members of the cohort formed had to

*Participants of the study Plant No 10 Hüls AG, Marl

Plant No 22 Bayer AG, Dormagen

Plant No 28 Erdöl Chemie (EC), Dormagen

Plant No 30 Henkel KGaA, Düsseldorf

Plant No 40 Bayer AG, Leverkusen

Plant No 50 Hoechst AG, Frankfurt

Plant No 51 Hoechst AG, Gendorf

Plant No 60 BASF AG, Ludwigshafen

N Tenkhoff,

E Prang

W Schack

H-J Engelhard

K Dietrich

N Kiesselbach

(Coordinator)

M J Stasik

H Höglmeier

W G Stocker

Initiator of study Verband der Chemischen Industrie (VCI) 
have been exposed to EO for at least 12 months before the closing date of the study (31 December 1982). The time of first exposure varied between 1928 and 1981 but for most cases started after 1950.

\section{SELECTION OF COHORT}

For all plants handling EO information was gathered from lists of names prepared by the personnel departments. This information was complemented by papers from the plants themselves-shift books, for example-concerning subjects previously exposed to EO and by notes from the occupational medical department concerning the "job history."

These lists were checked and completed where necessary. In addition, they were discussed in detail with the manager of the plant where the employees had a long exposure record to establish the following information:

Type and duration of exposure to EO for each separate person (minimum 12 months) who had worked predominantly or exclusively with apparatus containing EO (production or maintenance).

Date of beginning and end of this work.

Description of the type of work and mention of accidents or major breakdowns or similar important events.

Vital status at the date of closure-for active employees and for pensioners the available data of the medical, personnel, and pension departments were used.

For employees who had left the firms the local registries were asked for the new address. If a person was on the register he was coded as "alive." For foreign employees who had returned to their country of origin a letter was sent asking about present work or fellow countrymen remaining in the plant were asked for information. In the case of change to another company previous fellow shift workers could often give information.

\section{CAUSES OF DEATH}

Causes of death were obtained in several ways. For most, because of legal restriction, direct information from death certificates was not available and information came from the following sources:

lay statements,

information by the physician who last treated the patient either from his own notes or from hospital reports,

hospital reports, and

hospital reports including postmortem findings.

Information on malignant neoplasms was classified according to diagnostic validity as follows: $(a)$ clinically, (b) cytologically, (c) histological finding of a biopsy, and $(d)$ histological finding at operation. Whenever possible the date of the diagnosis of a tumour was documented. In the case of overlapping the highest category available was used for documentation.

\section{DATA PROTECTION}

The inquiry into the causes of death had to be carried out within the narrow limits given by the German data protection legislation and also was subject to the relevant laws of the penal code and those paragraphs of the medical code concerning professional secrecy.

By following this procedure completeness of the information was obtained to a large extent. For the statistical evaluation the data sheets have been made anonymous.

\section{CODING OF CAUSES OF DEATH}

The causes of death were coded by means of the International Classification of Diseases and Causes of Death (ICD) 9th revision of $1979 .{ }^{12}$ For deaths occurring before 1979 a transformation table (for the 8 th revision) was prepared and used.

\section{STATISTICAL METHODS}

All statistical tests were carried out at a significance level of $\alpha=5 \%$. The tests concerning risks of leukaemia are statistically confirmatory, since because of prior information a corresponding hypothesis was available before beginning the study ${ }^{67}$ These tests were performed one sided. All other tests, or total mortality, or other causes of death, for example, are explorative.

For the comparison of mortality of the subjects exposed to EO with the general population the SMR for age, sex, calendar time, and cause of death was determined. The ages were grouped into the usual five year classes.

For calculating observed values the mortality data of the vital statistics were available from 1951. For the few deaths before 1951 data from 1951 were used for comparison. Since the minimum exposure is one year the calculation of person-years under risk starts one year after the beginning of exposure (qualifying year). A second set of calculations ignoring the first ten years exposure was made to account for latency. The calculation was carried out using the program of Coleman et al. ${ }^{13}$ Significance tests were carried out assuming a Poisson distribution ${ }^{14}$ and confidence intervals for the SMRs were calculated according to Bailar and Ederer. ${ }^{15}$ The power of the study to detect a particular level of risk was also calculated ${ }^{16}$ Before pooling the data from all the plants a test on heterogeneity was performed. ${ }^{17}$

In one plant (plant 40) an internal control group was selected. For each exposed individual an unexposed control, matched for age, sex, and date of entry into the company was drawn at random. The mortality risks in both cohorts were compared by means of SMRs and McNemar's test. ${ }^{18}$

In the matched pairs analysis only those pairs in 
which at least one member has died and the other has survived are considered. If $R_{0}$ denotes the number of pairs where one member has died and the member exposed to EO has survived and $R_{1}$ denotes the reverse then the estimate of $\Theta$, the relative risk of the exposed, is $R_{1} / R_{0}$. Testing the null hypothesis-that is $H_{0}: \Theta=1$ is carried out by

$$
\chi^{2}=\frac{\left(\mathbf{R}_{0}-\mathbf{R}_{1}\right)^{2}}{\mathbf{R}_{0}+\mathbf{R}_{1}}
$$

The value of $\chi^{2}$ is distributed with one degree of freedom.

\section{Results}

STATISTICAL DESCRIPTION

A total of 2658 subjects were taken into the study. Those workers who were included in the study of Thiess $e \mathrm{al}^{8}$ were accepted only if they fulfilled the exposure requirement (minimum exposure of one year). By the closing date of the study (31 December 1982) 2327 subjects were alive and 268 had died, 68 from malignant neoplasms. For 63 subjects $(2 \cdot 4 \%)$ the vital status remained unknown (table 1 and figure).

Table 2 shows the sources of information on the causes of death whereas table 3 gives a general account of the duration of exposure and years since first exposure classified according to vital status and cause of death. The dead had had longer exposures; those who died from a neoplasm had a median exposure of 12.8 years and those who had died from other causes a median of 11.8 years. For those who were still alive at the end of the study the median duration of exposure was 9.5 years; for those whose vital status was unknown it was $3 \cdot 2$ years.

The findings are similar for the duration of risk. The total time of exposure was, wherever possible, divided into periods of "weak," "medium," and "strong" exposure. Of the 2658 members of the

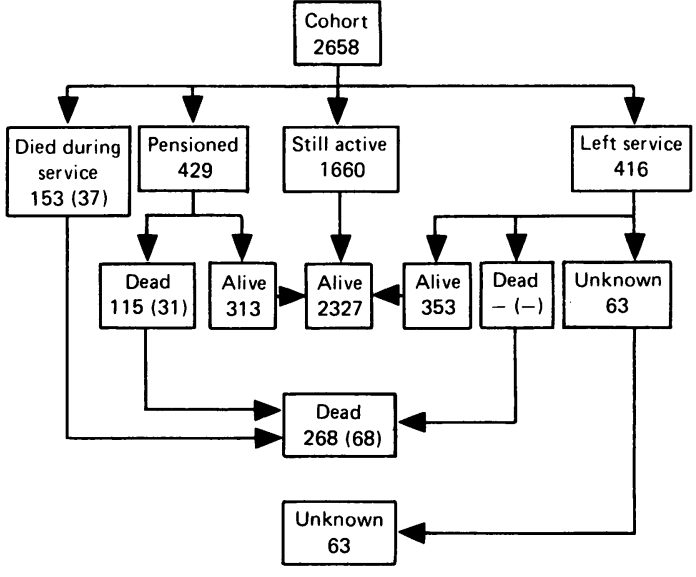

Summary of vital status and employment status of exposed men in all plants at 31 December 1982. (Number of deaths due to neoplasm shown in parentheses.)

cohort this information was available for 1786 $(67 \cdot 2 \%)$.

Table 4 shows the percentage distribution of the three exposure periods for the total duration, again differentiated according to the vital status. It may be seen that most members of the cohort had weak $(71.6 \%)$ or medium $(26.0 \%)$ exposure. No cases of accidents or acute overexposure were noted. For the survivors, $75.1 \%$ of the total exposure period was categorised as weak. For those who had died, this was so for $50 \%$ (death due to tumour) or $43.5 \%$ (death due to other causes) of their exposure period. For those with unknown vital status at the end of the study, only $37.3 \%$ of exposure period was weak. Of the 63 members of the cohort who had an unknown vital status at the end of the study, 25 came from Mediterranean countries and had returned home. In all, $108(4 \cdot 1 \%)$ of the exposed group came from these countries. For the separate plants the foreign popula-

Table 1 Summary data for cohort exposed to ethylene oxide

\begin{tabular}{|c|c|c|c|c|c|c|c|}
\hline \multirow[b]{3}{*}{ Plant No } & \multirow[b]{3}{*}{$\begin{array}{l}\text { No of } \\
\text { subjects }\end{array}$} & \multicolumn{6}{|c|}{ Vital status at end of study } \\
\hline & & \multirow[b]{2}{*}{ Alive } & \multicolumn{4}{|l|}{ Dead } & \multirow[b]{2}{*}{ Unknown } \\
\hline & & & $\begin{array}{l}\text { Malignan } \\
\text { ICD } \\
140-199\end{array}$ & $\begin{array}{l}\text { plasms } \\
I C D \\
200-203\end{array}$ & $\begin{array}{l}\text { Leukaemia } \\
\text { ICD } \\
204-208\end{array}$ & $\begin{array}{l}\text { All causes } \\
\text { ICD } \\
1-999\end{array}$ & \\
\hline $\begin{array}{l}10 \\
22 \\
28 \\
30 \\
40 \\
50 \\
51 \\
60\end{array}$ & $\begin{array}{r}581 \\
373 \\
180 \\
98 \\
246 \\
131 \\
445 \\
604\end{array}$ & $\begin{array}{r}474 \\
351 \\
169 \\
91 \\
218 \\
118 \\
409 \\
497\end{array}$ & $\begin{array}{r}20 \\
5 \\
2 \\
1 \\
6 \\
3 \\
9 \\
17\end{array}$ & $\begin{array}{l}\frac{1}{-} \\
\frac{-}{-} \\
\frac{1}{1}\end{array}$ & $\begin{array}{l}\bar{Z} \\
\overline{-} \\
\overline{1} \\
\frac{1}{1}\end{array}$ & $\begin{array}{r}99 \\
18 \\
8 \\
4 \\
24 \\
10 \\
33 \\
72\end{array}$ & $\begin{array}{r}8 \\
4 \\
3 \\
3 \\
4 \\
3 \\
3 \\
35\end{array}$ \\
\hline Total & 2658 & 2327 & 63 & 3 & 2 & 268 & 63 \\
\hline
\end{tabular}


Table 2 Sources of information of causes of death

\begin{tabular}{|c|c|c|c|c|c|c|c|c|}
\hline & 1 & 2 & 3 & 4 & 5 & 6 & 19 & Total \\
\hline $\begin{array}{l}\text { Malignant neoplasms } \\
\text { ICD 140-203 }\end{array}$ & $\begin{array}{c}4 \\
(6 \%)\end{array}$ & $\begin{array}{l}17 \\
(25 \%)\end{array}$ & 17 & 10 & $68 \%{ }^{17}$ & 1 & - & 66 \\
\hline $\begin{array}{l}\text { Leukaemia } \\
\text { ICD 204-208 }\end{array}$ & & & - & 1 & $100^{1}$ & - & - & 2 \\
\hline Cardiovascular system & $\begin{array}{l}13 \\
(11 \%)\end{array}$ & $\begin{array}{l}33 \\
(27 \%)\end{array}$ & 41 & 11 & $60 \%$ & 3 & 1 & 118 \\
\hline Unknown & - & 2 & - & - & - & - & 11 & 13 \\
\hline Injuries accidents & $\begin{array}{l}12 \\
(43 \%)\end{array}$ & $\begin{array}{c}5 \\
(18 \%)\end{array}$ & 9 & - & $39 \%$ & - & - & 28 \\
\hline Other & $\begin{array}{c}2 \\
(5 \%)\end{array}$ & $\begin{array}{l}17 \\
(41 \%)\end{array}$ & 7 & 1 & $41 \%{ }^{9}$ & - & 5 & 41 \\
\hline Total & $\begin{array}{l}31 \\
(11 \cdot 6 \%)\end{array}$ & $\begin{array}{l}74 \\
(27 \cdot 6 \%)\end{array}$ & 74 & 23 & $(54.5 \%)^{45}$ & 4 & $\begin{array}{l}17 \\
(6 \cdot 3 \%)\end{array}$ & 268 \\
\hline
\end{tabular}

$1=$ Lay information.

$2=$ Death certificate.

$3=$ Information from general practitioner.

$4=$ Written hospital report.

$5=$ Discussion with hospital physician.

$6=$ Postmortem findings.

$19=$ Source unknown or not indicated.

tion varied between zero and $11.5 \%$; none of these foreign workers had died during the study.

\section{STANDARDISED MORTALITY RATIOS}

The mortality of the subjects exposed to EO was compared with that of the population of the Federal Republic of Germany and also with that of the state in which the particular plant was situated. Table 5 shows the SMRs for some selected causes of death by comparison with the population of the Federal Republic. The SMRs calculated from rates in the separate states differ little from those in table 5 . None of the SMR values differs significantly from unity. The overall SMR was 0.87 and may be due to a healthy worker effect. For all malignant neoplasms (ICD 140-208) the SMR was 0.97; there was no excess mortality from leukaemia (SMR 0.85). Only two cases of leukaemia were found among the exposed group in two plants. The power to detect an increased mortality from leukaemia in this study was $33 \%$ assuming a relative risk of two. With a relative

Table 3 Duration of years and years since first exposure

\begin{tabular}{|c|c|c|c|c|}
\hline State & No & Min & $\operatorname{Max}$ & Median \\
\hline \multicolumn{5}{|c|}{ Duration of exposure $(y)$} \\
\hline $\begin{array}{l}\text { Alive } \\
\text { Dead (tumour) } \\
\text { Dead (other cause) } \\
\text { Unknown }\end{array}$ & $\begin{array}{r}2327 \\
68 \\
200 \\
63\end{array}$ & $\begin{array}{l}1.0 \\
1 \cdot 3 \\
1 \cdot 0 \\
1 \cdot 1\end{array}$ & $\begin{array}{l}41 \cdot 8 \\
37 \cdot 3 \\
40 \cdot 1 \\
17 \cdot 8\end{array}$ & $\begin{array}{r}9 \cdot 5 \\
12 \cdot 8 \\
11 \cdot 8 \\
3 \cdot 2\end{array}$ \\
\hline Total & 2658 & $1 \cdot 0$ & $41 \cdot 8$ & $9 \cdot 6$ \\
\hline \multicolumn{5}{|c|}{ Years since first exposure } \\
\hline $\begin{array}{l}\text { Alive } \\
\text { Dead (tumour) } \\
\text { Dead (other cause) } \\
\text { Unknown }\end{array}$ & $\begin{array}{r}2322 \\
68 \\
200 \\
62\end{array}$ & $\begin{array}{l}1 \cdot 0 \\
2 \cdot 6 \\
1 \cdot 4 \\
1 \cdot 0\end{array}$ & $\begin{array}{l}62 \cdot 6 \\
41 \cdot 4 \\
44 \cdot 9 \\
24 \cdot 7\end{array}$ & $\begin{array}{r}15 \cdot 2 \\
21 \cdot 1 \\
19 \cdot 6 \\
7 \cdot 1\end{array}$ \\
\hline Total & 2658 & $1 \cdot 0$ & $62 \cdot 6$ & $15 \cdot 5$ \\
\hline
\end{tabular}

risk of five the power is raised to $98 \%$ and is greater than $99 \%$ if a risk of 10 is assumed, as Hogstedt et al suggest. ${ }^{6}$ The SMRs obtained allowing more than 10 years are similar to those reported above.

The SMRs for cancers of the oesophagus $(S M R=2.0)$ and stomach $(S M R=1.38)$ are the highest of those found for malignant neoplasms but neither is statistically significant. In table 6 the SMRs for stomach cancer are differentiated according to level and duration of exposure and period of risk; each subject was put into the category in which he had worked the longest. There was no increase of risk with increasing level of exposure.

A case-control analysis was carried out for stomach cancer. For each case five matched controls were selected from the cohort. The matching criteria were: year of birth ( \pm five years), company, plant, and entry into the company ( $t$ five years). The test criterion was level of exposure. For five of the 14 cases no information as to the level of exposure was available and so the analysis could be carried out for only nine cases. All the matched pairs had the same level of exposure and thus there was no indication of a dose related effect. (A similar analysis was not undertaken for cancer of the oesophagus as there were only three cases.)

Table 4 Distribution of exposure times over periods of weak, medium, or strong exposure as a percentage of total exposure

\begin{tabular}{lrclll}
\hline State & No & $\begin{array}{l}\text { No } \\
\text { infor- } \\
\text { mation }\end{array}$ & $\begin{array}{l}\text { Weak } \\
(\%)\end{array}$ & $\begin{array}{l}\text { Medium } \\
(\%)\end{array}$ & $\begin{array}{l}\text { Strong } \\
(\%)\end{array}$ \\
\hline Alive & 1588 & 739 & 75.1 & 22.3 & 2.5 \\
Dead (tumour) & 42 & 26 & 50 & 49.3 & 0.7 \\
Dead (other cause) & 107 & 93 & 43.5 & 54.7 & 1.8 \\
Unknown & 49 & 14 & 37.3 & 61.9 & 0.8 \\
Total & 1786 & 872 & 71.6 & 26.0 & 2.4 \\
\hline
\end{tabular}


Table 5 SMR values for all plants

\begin{tabular}{|c|c|c|c|c|c|}
\hline Cause of death & $I C D-9$ & Obs & $\operatorname{Exp}$ & $S M R$ & $95 \% C I$ \\
\hline $\begin{array}{l}\text { Malignant neoplasms: } \\
\text { Except: } 200-208 \\
\text { Oesophagus } \\
\text { Stomach } \\
\text { Large intestine } \\
\text { Colon + rectum } \\
\text { Lung } \\
\text { Urogenital } \\
\text { Other } \\
\text { Malignant neoplasm lymphatic + } \\
\text { haematopoietic tissue }\end{array}$ & $\begin{array}{l}140-208 \\
140-199 \\
150 \\
151 \\
153 \\
154 \\
162 \\
179-189 \\
200-208\end{array}$ & $\begin{array}{r}68 \\
63 \\
3 \\
14 \\
14 \\
3 \\
2 \\
23 \\
4 \\
4 \\
14 \\
5\end{array}$ & $\begin{array}{r}69 \cdot 85 \\
64 \cdot 86 \\
1 \cdot 50 \\
10 \cdot 15 \\
4 \cdot 99 \\
3 \cdot 24 \\
19 \cdot 86 \\
8 \cdot 97 \\
16 \cdot 15 \\
4.99\end{array}$ & $\begin{array}{l}0.97 \\
0.97 \\
2.00 \\
1.38 \\
0.60 \\
0.62 \\
1 \cdot 16 \\
0 \cdot 45 \\
0 \cdot 87 \\
1.00\end{array}$ & $\begin{array}{l}0 \cdot 76-1 \cdot 24 \\
0 \cdot 75-1 \cdot 24 \\
0 \cdot 41-5 \cdot 85 \\
0 \cdot 75-2 \cdot 31 \\
0 \cdot 12-1 \cdot 76 \\
0 \cdot 07-2 \cdot 23 \\
0 \cdot 73-1 \cdot 74 \\
0 \cdot 12-1 \cdot 14 \\
0 \cdot 47-1 \cdot 45 \\
0 \cdot 32-2 \cdot 34\end{array}$ \\
\hline $\begin{array}{l}\text { Leukaemia } \\
\text { Other } \\
\text { Cardiovascular diseases } \\
\text { Trauma + poisoning } \\
\text { Other } \\
\text { All causes }\end{array}$ & $\begin{array}{l}204-208 \\
200-203 \\
390-459 \\
800-999 \\
001-999\end{array}$ & $\begin{array}{r}2 \\
3 \\
118 \\
28 \\
54 \\
268\end{array}$ & $\begin{array}{r}2 \cdot 35 \\
2 \cdot 64 \\
115 \cdot 73 \\
40 \cdot 37 \\
81 \cdot 61 \\
307 \cdot 56\end{array}$ & $\begin{array}{l}0.85 \\
1 \cdot 14 \\
1.02 \\
0 \cdot 69 \\
0 \cdot 66 \\
0.87\end{array}$ & $\begin{array}{l}0.10-3.07 \\
0 \cdot 23-3.32 \\
0.84-1 \cdot 22 \\
0.46-1.00 \\
0.50-0.86 \\
0.77-0.98\end{array}$ \\
\hline
\end{tabular}

RESULTS OF COMPARISON WITH AN INTERNAL CONTROL GROUP

In one plant (plant 40) a non-exposed control group was selected at random, matched for date of birth, sex, and date of entry into the company with the exposed group. For one member of the test group no match could be found. Twenty four of the exposed group had died whereas of the 245 in the control group, 19 had died, four from malignant neoplasms; among these one had died from myelogenous leukaemia. For one of the control group the vital status at 31 December 1982 has remained unknown.

The SMR values of the test group are higher than those of the control group (table 7) but they do not differ significantly.

\section{MCNEMAR TEST}

In 202 of the 242 pairs both partners were alive at the end of the observation period. For the lost cases (four in the test group and one in the control group) the matched member was alive. Of the remaining 38 pairs, at least one had died. In five cases both partners

Table 6 Mortality from stomach cancer by exposure level (years of total exposure and years since first exposure)

\begin{tabular}{|c|c|c|c|c|c|}
\hline & \multirow[b]{2}{*}{ No } & \multicolumn{2}{|c|}{ No of deaths } & \multirow[b]{2}{*}{$S M R$} & \multirow[b]{2}{*}{$95 \% C I$} \\
\hline & & Obs & $E x p$ & & \\
\hline \multirow{2}{*}{$\begin{array}{l}\text { Total } \\
\text { Level of exposure: } \\
\text { Weak } \\
\text { Medium } \\
\text { High } \\
\text { No information }\end{array}$} & 2658 & 14 & $10 \cdot 15$ & $1 \cdot 38$ & $0 \cdot 75-2 \cdot 31$ \\
\hline & $\begin{array}{r}1253 \\
492 \\
41 \\
872\end{array}$ & $\begin{array}{l}4 \\
5 \\
0 \\
5\end{array}$ & $\begin{array}{l}2 \cdot 62 \\
3 \cdot 01 \\
0 \cdot 08 \\
4 \cdot 44\end{array}$ & $\begin{array}{l}1.53 \\
1.66 \\
0.00 \\
1.13\end{array}$ & $\begin{array}{l}0.42-3.91 \\
0.54-3.87 \\
0.00-36.27 \\
0.37-2.63\end{array}$ \\
\hline \multicolumn{6}{|c|}{ Years of total exposure: } \\
\hline $\begin{array}{l}0-4 \\
5-9 \\
10-14 \\
\geqslant 15\end{array}$ & $\begin{array}{l}705 \\
612 \\
524 \\
817\end{array}$ & $\begin{array}{l}2 \\
3 \\
4 \\
5\end{array}$ & $\begin{array}{l}1 \cdot 33 \\
1 \cdot 69 \\
2 \cdot 03 \\
5 \cdot 10\end{array}$ & $\begin{array}{l}1.50 \\
1.78 \\
1.97 \\
0.98\end{array}$ & $\begin{array}{l}0 \cdot 18-5 \cdot 43 \\
0 \cdot 37-5 \cdot 19 \\
0 \cdot 54-5 \cdot 05 \\
0 \cdot 32-2 \cdot 29\end{array}$ \\
\hline \multicolumn{6}{|c|}{ Years since first exposure: } \\
\hline $\begin{array}{l}\leqslant 9 \\
10-19 \\
\geqslant 20\end{array}$ & $\begin{array}{r}2658 \\
1769 \\
809\end{array}$ & $\begin{array}{l}3 \\
5 \\
6\end{array}$ & $\begin{array}{l}2 \cdot 49 \\
3 \cdot 57 \\
4 \cdot 10\end{array}$ & $\begin{array}{l}1 \cdot 21 \\
1 \cdot 40 \\
1 \cdot 47\end{array}$ & $\begin{array}{l}0.25-3.53 \\
0.46-3.27 \\
0.54-3.19\end{array}$ \\
\hline
\end{tabular}

had died, in four cases the exposed partner had died first, and in 19 cases the exposed partner died and the control had survived. In 14 cases the control had died and the case survived. The relative mortality is thus determined as $\hat{\theta}=(4+19) /(1=14)=1.53$; this does not differ significantly from $1(\mathrm{p}>0.05)$.

If only those who died from a neoplasm are considered (six exposed and four controls) the following picture is obtained: all those who died from a tumour were survived by the corresponding member except for one case. One case from the control group died after his exposed partner. The relative risk thus is determined by

$\hat{\theta}=(6+1) /(4-1)=2 \cdot 33(\mathrm{p}>0.05)$.

\section{Discussion}

No excess mortality from leukaemia was found in this study. Only two cases of leukaemia were observed in the exposed group (in two plants) giving an SMR of 0.85 calculated for the Federal Republic. The SMRs for malignant neoplasms of the oesophagus (2.0) and

Table 7 SMRs of exposed subjects and of matched controls (plant 40). (Number of observed deaths shown in parentheses.)

\begin{tabular}{|c|c|c|c|}
\hline \multirow[b]{2}{*}{ Cause of death pairs } & \multirow[b]{2}{*}{ ICD 9} & \multicolumn{2}{|c|}{ SMR values } \\
\hline & & Exposed & Matched \\
\hline $\begin{array}{l}\text { Malignant neoplasms: } \\
\text { Malignant neoplasms without } \\
\text { 200-208 }\end{array}$ & $\begin{array}{l}140-208 \\
140-199\end{array}$ & $\begin{array}{l}1 \cdot 14(6) \\
1 \cdot 23(6)\end{array}$ & $\begin{array}{l}0.71(4) \\
0.57(3)\end{array}$ \\
\hline $\begin{array}{l}\text { Stomach } \\
\text { Large intestine } \\
\text { Lung } \\
\text { Urogenital } \\
\text { Malignant neoplasms of the } \\
\text { lymphatic and haematopoietic } \\
\text { tissues }\end{array}$ & $\begin{array}{l}151 \\
153 \\
162 \\
179-189 \\
200-208\end{array}$ & $\begin{array}{l}1.37(1) \\
2.63(1) \\
2.01(3) \\
1.56(1) \\
0.00(0)\end{array}$ & $\begin{array}{l}1.27(1) \\
0.00(0) \\
0.63(1) \\
1.49(1) \\
2 \cdot 38(1)\end{array}$ \\
\hline $\begin{array}{l}\text { Leukaemia } \\
\text { Cardiovascular diseases } \\
\text { Trauma, intoxication } \\
\text { Other } \\
\text { All causes of death }\end{array}$ & $\begin{array}{l}204-208 \\
390-459 \\
800-999 \\
001-999\end{array}$ & $\begin{array}{l}0.00(0) \\
1.97(9) \\
1.16(4) \\
0.79(5) \\
1.02(24)\end{array}$ & $\begin{array}{l}5 \cdot 26(1) \\
0 \cdot 89(8) \\
0.85(3) \\
0.60(4) \\
0.77(19)\end{array}$ \\
\hline
\end{tabular}


of the stomach $(1 \cdot 38)$ are raised but are not statistically significant.

The only known human carcinogens to which there was a possible additional exposure in some working areas were 4-amino-diphenyl, 2-naphtylamine, and benzene. Bladder tumours were not observed in the cohort, however. Since there was no increased incidence of leukaemia, the possibility of a mixed exposure to EO and benzene is not relevant.

Causes of death were obtained by the so called "best available information" since, because of legal regulations in the Federal Republic, it is usually not possible to get information for epidemiological studies directly from the death certificate. ${ }^{19}$ For more than half the cases the information came from a more comprehensive source. Only about $10 \%$ are based on statements made by lay people, though the quality of this information is usually surprisingly good. ${ }^{20}$ In our cohort they concern almost exclusively deaths caused by cardiovascular diseases and fatal accidents.

Thus a so called observer sensitivity bias is possible: the expected values were calculated according to the information stated on the death certificates that are used for the official mortality statistics. The observed values, however, were calculated by the often better documented medical notes. In the absence of this bias the SMR values would probably tend to be even lower than they are described here.

For the analysis using an internal control group observer sensitivity bias could not occur, since the same method of data collection was applied.

For $6.3 \%$ of the cohort there was no information concerning the cause of death. This problem of lost cases particularly concerns the foreign employees from the Mediterranean countries $(4 \cdot 1 \%$ of the total cohort) who had left their company or the Federal Republic, or both. For $23 \%$ of these 108 members of the cohort, vital status was not known. If these foreign employees are left out of the calculations the number of observed deaths is not altered. The reduction of person-years at risk of approximately $4 \%$ would lead to minor changes in the SMRs.

So called type II errors, the probability of overlooking an actual difference between the expected and observed number of deaths, depends among other things on the size of the cohort. If one assumes that, in the case of the exposed group, the mortality from leukaemia was twice that calculated for the present cohort then the type II error would be $67 \%$. With a probability of $67 \%$ such a rise in mortality would have been overlooked (power $=33 \%$ ). With a relative risk as high as that reported by Hogstedt et al $(S M R \approx 10)^{6}$ this probability would have been $<1 \%$ (power > 99\%).

Comparison of SMRs and the use of the McNemar test in matched pairs analysis showed no significant differences between exposed and control groups. In the exposed group there was no case of leukaemia but in the control group there was one. A tendency in the matched pairs for higher total mortality figures and for malignant neoplasms as cause of death in the exposed group is perhaps an indication for further work despite the fact that the differences were not significant. Thus the raised risk for leukaemia described by Hogstedt et al could not be confirmed by our results which are more comparable with those of other epidemiological studies. ${ }^{89}$

In a recent study no clear excess of leukaemia and no increase of stomach cancer was found. ${ }^{22}$ The SMRs for carcinoma of the oesophagus and stomach in our study are not significantly raised, although Hogstedt $e t$ al found an SMR > 9 for carcinoma of the stomach as for carcinoma of the oesophagus; the SMR for carcinoma of the stomach was statistically significant. ${ }^{21}$ It should be noted that at the time of the study in Sweden the ratio of mortality due to cancer of the stomach to that of leukaemia was $1: 1$ whereas in the Federal Republic of Germany it is 2.5:1. After completion of our study, one case of carcinoma of the stomach and two cases of carcinoma of the oesophagus have occurred in members of the cohort; this will certainly stimulate the follow up of this population.

1 Henschler D. Ethylenoxid. MAK-Werten: Deutsche Forschungsgemeinschaft, Toxikologisch-arbeits-medizinische Begründung von MAK-Werten, 1984.

2 Thiess AM. Beobachtungen über Gesundheitsschädigungen durch Einwirkung von Ethylenoxid. Arch Toxicol 1963;20:127-40.

3 Thiess AM, Schwegler H, Fleig I, Stocker WG. Mutagenicity study of workers exposed to alkylene oxides (ethylene oxide/ propylene oxide) and derivatives. JOccup Med 1982;23:343-7.

4 Laurent C, Frederic J, Leonard AY. Sister chromatid exchange frequency in workers exposed to high levels of ethylene oxide in a hospital sterilization service. Int Arch Occup Environ Health 1984;54:33-43.

5 Hemminki K, Mutanen P, Saloniemi I, Niemi M-L, Vainio H. Spontaneous abortions in hospital staff engaged in sterilising instruments with chemical agents. $B r M e d ~ J 1982 ; 285: 1461-3$.

6 Hogstedt C, Malmqvist N, Wadman B. Leukemia in workers exposed to ethylene oxide. JAMA 1979;241:1132-3.

7 Hogstedt C, Rohlen O, Berndtsson BS, Axelson O, Ehrenberg L. A cohort study of mortality and cancer incidence in ethylene oxide production workers. $\mathrm{Br} J$ Ind Med 1979;36:276-80.

8 Thiess AM, Frentzel-Beyme R, Link R, Stocker WG. Mortality study on employees exposed to alkylene oxides (ethylene oxide/propylene oxide) and their derivatives. In: Prevention of occupational cancer: international symposium. Geneva: International Labour Office, 1981:249-59. (Occupational safety and health series No 46 .)

9 Morgan RW, Claxton KW, Divine BJ, Kaplan SD, Harris VB. Mortality among ethylene oxide workers. J Occup Med 1981;23:767-70.

10 Anonymous. Ethylene oxide-a human carcinogen? Lancet 1989; ii:201-2.

11 World Health Organisation. Ethylene oxide. Geneva: WHO, 1985.

12 International Classification of Diseases. Geneva: World Health Organisation, 1979. (Rev 9.)

13 Coleman M, Douglas A, Hermon C, Peto J. Cohort-study analysis with a Fortran-computer program. Int J Epidemiol 1986;15:134-7.

14 Breslow NE, Day NE. The standardized mortality ratio. In: Biostatics in biomedical, public health and environmental sciences. Amsterdam: Elsevier, 1985. 
15 Bailar JC, Ederer F. Significance factors for the ratio of a Poisson-variable to its expectation. Biometrics 1964;20: 639-43.

16 Beaumont JJ, Breslow NE. Power consideration in epidemiological studies of vinyl-chloride workers. $\mathrm{Am} \mathrm{J}$ Epidemiol 1981;14:725-43.

17 Saracci R, Simonato L, Acheson ED, et al. Mortality and incidence of cancer of workers in the man made vitreous fibres producing industry: an international investigation at 13 European plants. Br J Ind Med 1984;41:425-36.

18 Kalbfleisch JD, Prentice RL. The statistical analysis of failure time data. New York: Wiley, 1980.

19 Kiesselbach N, Lange H-J, Korallus U. Möglichkeiten und Qualitätssicherung epidemiologischer Untersuchungen im betriebsärztlichen Bereich. In: Verhandlungen der Deutschen 을 Gesellschaft für Arbeitsmedizin. 25. Jahrestagung in Dortmund. Gentner Verlag, 1985;627-33.

20 Claude J, Eilber U, Chow KW, Frentzel-Beyme R. Validity of cause of death statements from relatives. Int Arch Occup Environ Health 1984;54:335-43.

21 Hogstedt C, Aringer L, Gustavsson A. Epidemiologic support $\overline{\bar{\sigma}}$ for ethylene oxide as a cancer-causing agent. $J A M A \overrightarrow{\mathbb{D}}$ $1986 ; 255: 1575-8$

22 Gardner MJ, Coggon D, Pannett B, Harris EC. A follow up study of workers exposed to ethylene oxide. $\mathrm{Br} J$ Ind Med 1989;46:860-5.

Accepted 5 May 1989

\section{A mediaeval accident at work}

During the mediaeval period two great industries, agriculture and building, occupied the mass of the working population in this country either directly or in the trades allied to them. The great delight in researching this period is in studying the illustrations depicting men and women at work in manuscripts, painting, sculpture, or in carving. The burden of ill health resulting from work must have been considerable and allusions are sometimes made to it, particularly in reference to mining, but detailed accounts of occupational diseases seem very thin on the ground. There is little doubt that those who were engaged in building must have suffered a good deal from accidental injuries and we know that a number of cathedrals, for example, collapsed with loss of life. Only when someone of importance was injured, however, do we find a written account; thus we know that Williams of Sens who supervised the rebuilding of Canterbury Cathedral after the fire of 1174 fell from some scaffolding and sustained serious injury but survived. I have been able to find only a few illustrations of accidentso at work, one of which is shown here. It comes from a double을 sided painting by Lorenzo di Niccolo Serini (1342-1411) depicting episodes in the life of St Vita. The original is in $\overrightarrow{\overrightarrow{\vec{T}}}$ the town museum of San Gimignano in Italy. A workman is 3 shown putting a roof on a small building and as he is working the scaffolding on which he is standing breaks but his fall to the ground is prevented by the miraculous intervention of the saint; judging from the state of the scaffolding, this was the only safety measure available to 3 him. Details of other illustrations of mediaeval hazards ato work would be much appreciated.

HA WALDRON Editor

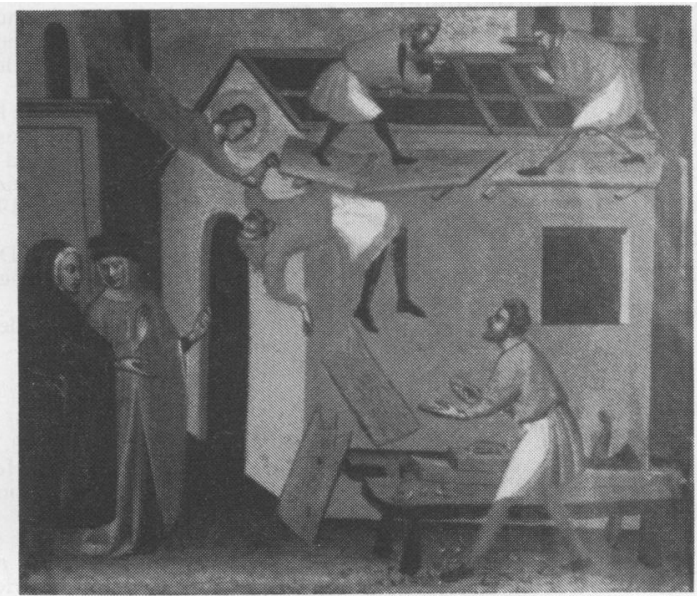

